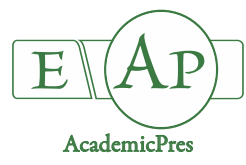

Available online: www.notulaebotanicae.ro

Print ISSN 0255-965X; Electronic 1842-4309

Not Bot Horti Agrobo, 2019, 47(2):450-457. DOI:47.25835/nbha47111245

Original Article

\title{
Vegetative Growth and Quality of Blueberry Fruit Cultivated in Chihuahua, Mexico
}

\author{
Jessica I. CERA-CAMPOS, Juan L. JACOBO-CUELLAR, María J. \\ RODRIGUEZ-ROQUE, Rafael Á. PARRA-QUEZADA, Mayra C. SOTO- \\ CABALLERO, Ramona PÉREZ-LEAL, Oscar CRUZ-ALVAREZ*
}

\author{
Autonomous University of Chihuahua, Faculty of Agrotechnological Sciences, Pascual Orozco Avenue, Campus 1, Santo Niño, CP 31350 \\ Chibuahua,Mexico;jessi_cera@hotmail.com;jljacobo@uach.mx; janeth2807@gmail.com;raparra@uach.mx; \\ mayrasotocaballero@gmail.com;perezleal@hotmail.com; ocruz@uach.mx ( ${ }^{*}$ correspondingauthor)
}

\begin{abstract}
The aim of this investigation was to evaluate the vegetative growth and some physicochemical quality parameters in fruits of different varieties of blueberries grown with amendments applied to the soil. The experimental design was completely randomized according to factorial treatments with nine replications. Length and number of shoots, flower buds number, total soluble solids (TSS), pH, color, total anthocyanins (TA), total phenols (TP) and antioxidant capacity (AC) were evaluated. The application of gypsum, sulphur and compost increased the shoots number in the varieties 'Bluejay' and 'Duke' with values from 15 and 17.5, respectively. The 'Duke' variety was the latest with regard to the flowering stage, evading the problem of frost. Among varieties, 'Bluejay' and 'Blueray' stood out for presenting fruits with greater acidity and antioxidant capacity (89.1 and $91.5 \%$ DPPH inhibition, respectively), however, the TP was higher in 'Bluejay' (701.6 mg gallic acid $100 \mathrm{~g}^{-1}$ ). The use of gypsum, sulphur and compost allows obtaining fruits with high soluble solids content $\left(9.8^{\circ} \mathrm{Brix}\right)$, however, the antioxidant capacity was similar when pine peel was included, with AC values from 91.4 and $88.8 \%$ DPPH inhibition, respectively. The amendments such as gypsum, sulphur and compost incorporated into the soil allow an adequate vegetative growth and the obtaining of blueberry fruits with physicochemical quality characteristics acceptable for their commercialization.
\end{abstract}

Keywords: agronomic management; amendments; antioxidant capacity; flowering; total phenols; Vaccinium corymbosum L. Abbreviations: Bj: Bluejay; Br: Blueray; g: gypsum; s: sulphur; c: compost; pb: pine bark; B: brightness; C: chromaticity; TSS: total soluble solids; TA: total anthocyanin, TP: total phenols; AC: antioxidant capacity.

\section{Introduction}

In Mexico, the State of Chihuahua is the largest producer of apples [Malus sylvestris (L) Mill. var. domestica (Borkh) Mansf.] with $84.4 \%$ total planted area (28,344 ha), where the municipalities of Cuauhtémoc (8,319 ha), Guerrero (6328 ha) and Namiquipa (5,117 ha) represent $69.7 \%$ of this area (ALIS, 2017). However, $80 \%$ of orchards are characterized by having plant densities of less than 2500 trees ha $^{-1}$ (Ramírez et al., 2011), extensive use of pesticides and labor (Ramírez-Legarreta et al., 2008), characteristics that limit the obtaining of high yields and consequently reduce the producer's income (Angeletti et al., 2010). In this sense, Ríos et al. (2017) indicate that the apple producers of Cuauhtémoc Chihuahua, with production systems of low and high technological level, $80 \%$ of variation in monetary income and $41.8 \%$ with medium technology levels; where according to Ordoñez (2016) the proportion between the different technological strata (low, medium and high) are distributed in 20,60 and 20\%, respectively.

As part of climate change, a variable interannual behavior is estimated with respect to environmental temperature and precipitation levels (Ramírez et al., 2011); what makes it essential, the search for crops with lower water requirements, cold storage needs and greater profitability (Ríos et al., 2017). An interesting alternative is represented by blueberries cultivation (Vaccinium corymbosum L.). Canada and United States are the largest producers of this crop worldwide, but they are also strong consumers, unable to satisfy the volume of internal consumption, which increases during the winter period since they are highly demanded as a fresh product (ALIS, 2017; Mditshwa et al., 2017). Countries that have favourable soil and climatic conditions for blueberries cultivation (Chile, Argentina and Mexico) have the 
possibility of satisfying this demand and obtaining highly competitive prices (Lobos et al., 2011; Muñoz-Vega et al., 2016).

The first registry of blueberry plantations in Mexico goes back to the 70's decade in the north zone of Puebla (Zacatlan), where the potential and adaptation level of the crop were evaluated. Since 2003 blueberries cultivation was reintroduced to the Municipality Los Reyes in the state of Michoacán and from there it quickly expanded to Baja California, Colima, Jalisco and Sinaloa (ALIS, 2017).

The geographical proximity to the United States assures Mexico of competitive advantages that have allowed it to be the leading exporting country of this fruit. According to figures in the 2017 report of the Secretariat of Agriculture, Livestock, Rural Development, Fisheries and Food (SALRDFF), the volume exported amounts to 18,000 tons, mainly to United States and Canada; and in smaller proportion to Europe (Netherlands) and Asia (Japan) with a value superior to 180 million dollars (ALIS, 2017).

As indicated above, blueberry crop has a high market potential with high profit margins $\left(\$ 130,432.18 \mathrm{ha}^{-1}\right)$ (ALIS, 2017) and with different production systems (open field and greenhouse) that can be easily complemented with organic management and adapted to the technological conditions of the producers (Muñoz-Vega et al., 2016). However, the high economic cost represented by the initial establishment and maintenance of production (Hummer $e t$ al., 2007), increase the need to have evaluation plots with commercial varieties, where technical information on their vegetative behaviour and fruit quality can be obtained in the edaphoclimatic conditions prevailing in the study area, and that can be offered as a viable alternative from the point of economic and technical view to the apple producers interested in the production of blueberry. Therefore, the aim of this research was to evaluate the vegetative growth and some parameters of physicochemical quality in blueberries grown with different amendments applied to the soil.

\section{Materials and Methods}

\section{Experiment location and plant material}

The experiment was carried out during the months April-June 2016 in the commercial orchard called "La Finca" owned by the company "La norteñita S.A. de C.V.". The evaluation site is located in the municipality of Cusihuiriachi in the south-central part of the State of Chihuahua, Mexico (28 $06^{\prime}$ 53.6' N; $107^{\circ} 03^{\prime} 20.7^{\prime \prime} \mathrm{W}$ ) at 2020 meters above sea level (masl), with a precipitation and average annual temperature of $496 \mathrm{~mm}$ and $18^{\circ} \mathrm{C}$, respectively. Soil presented silty clay texture, organic matter (2.58\%), $\mathrm{pH}(6.6)$, electrical conductivity $(0.171 \mathrm{dS} \mathrm{m}$ ) and porosity of $37.2 \%$. Plant material consisted of three varieties of blueberry (Bluejay, Blueray and Duke), which were obtained in March 2015 at Michigan State University Extension (MSUE), United States.

Maximum and minimum temperatures, probability of frost and accumulation of degree days

It was used information of maximum and minimum temperatures obtained by a agroclimate automatic station Campbell Scientific with data logger CR 10X (Net of
Agroclimate Stations from the Regional Agricultural Union of Fruit producers of Chihuahua State), equipped with different sensors for the registry of climate variables and located at $125 \mathrm{~m}$ from the experimental site. The temperature data used corresponded to years 2000-2017, which were reviewed, corrected and validated by those generated by another nearby agroclimate station. The probability of frost for a temperature of $-2^{\circ} \mathrm{C}$ was calculated based on the procedure proposed by Ortiz (1987).

From April 15 to the end of the flowering stage, heat units were calculated with information from this agroclimate station and with critical temperatures of 4.5 and $35^{\circ} \mathrm{C}$ in the platform of "University of California Agriculture and Natural Resourses" (https://www.ipm. ucanr.edu/Weather/index.html). Heat units were reported during the flowering event.

\section{Crop management}

Blueberry varieties were transplanted in April 2015 bare-rooted at a plants distance from each other of $0.40 \mathrm{~m}$ on furrows with dimensions of 50x0.90x0.25 m (length $\mathrm{x}$ width $\times$ height), and with separation of $0.90 \mathrm{~m}$ between them. Humidity maintenance was realized by a water drip system, with an average output of $1.9 \mathrm{~L} / \mathrm{plant}$, applied at three days intervals. Foliar applications of Stimplex (Acadian AgriTech, Canada) were done (bio-stimulant formulate with marine algae extract) and of Secure 4-1-1 (BWF Banducci Inc, USA) a liquid fish-based fertilizer. Weed control was manual on the furrows and mechanical between them. The harvested fruits for lab analysis were distinguished for their uniform and intense dark blue color (ripeness for consumption), without evidence of mechanical damage and/or attacks of plagues or sickness. The evaluation of quality variables in the fruit was done in the Horticulture Physiology and Technology laboratory of the Faculty of Agrotechnological Sciences of Autonomous University of Chihuahua.

\section{Experimental design}

Treatments were established under the experimental completely random design with arrangement of treatments factorial type $3^{*} 3$, with three varieties of highbush blueberry types (Bluejay, Blueray y Duke) and three amendments (gypsum + sulphur (1); gypsum + sulphur + compost (2), and gypsum + sulphur + compost + pine bark (3)), the quantity applied of gypsum, sulphur, compost and pine bark (beef cattle manure with remains of apple and woodchips) was of $1.0,0.5,3.0$ and $3.0 \mathrm{~kg} \mathrm{~m}^{-1}$, respectively. One plant was used as experimental unit and nine for description such as length and number of sprouts. In relation to fruit quality, it was used $10 \mathrm{~g}$ of fruits as experimental unit for the evaluation of total soluble solids, $\mathrm{pH}$ and color. By comparison, with $20 \mathrm{~g}$ of fruit were determined the total anthocyanins, total phenols, and antioxidant capacity. All evaluations of fruit quality had four replications.

\section{Variables evaluated \\ Length and number of sprouts}

Its evaluation was of sprouts belonging to the actual growth cycle; with conventional meter measuring tape it was determined its length $(\mathrm{cm})$ and simultaneously sprout number was counted. Data was collected every eight days during the period of April-June 2016. 
452

\section{Flowering}

Buds were counted in nine trees per variety, distributed in the middle part of the same and considering every ordinal quadrant (north, south, east and west). The number of buds was variable and depended on the availability per variety. The number of flower buds was recorded per variety and date of evaluation.

\section{Total soluble solids (TSS)}

It was quantified with a portable automatic digital refractometer SMART-1 (ATAGO', USA), for this it was extracted and placed on the prism surface one drop of fruit juice. The results are given in ${ }^{\circ} \mathrm{Brix}$.

\section{$p H$}

It was determined with a $\mathrm{pH}$ measurer series $\mathrm{HI}$ 5521(HANNA Instruments, USA.) with a range of $\mathrm{pH} 0$ 14 and with a precision degree of \pm 0.01 . The equipment was calibrated with a reference solution of $\mathrm{pH} 4$ and 7 .

\section{Color}

It was realized upon fruit epidermis in the equatorial region, through a portable tri-stimulant colorimeter series CR-300 (Konica Minolta, USA), registering initial values $L^{*}, a^{*} b^{*}$. Later it was determined chromaticity $=\left(a^{2}+b^{2}\right)^{1 / 2}$, tone $=$ angle hue $=\arctan \left(\mathrm{b}^{*} \mathrm{a}^{-1}\right)$ and brightness with a direct data of "L" indicated by the machine.

\section{Extract preparation}

A portion of $5 \mathrm{~g}$ of fresh blueberry was vigorously mixed with $10 \mathrm{~mL}$ of acidified methanol $(0.1 \% \mathrm{HCl})$ at room temperature. Afterwards, the extracts were filtered and stored at $-20^{\circ} \mathrm{C}$ until analysis.

The extracts were made with four replications and they were used for determining the total anthocyanin content, total phenols and antioxidant capacity.

\section{Total anthocyanin (TA)}

Total anthocyanins were determined according to the $\mathrm{pH}$ differential method reported by Wrolstad (1976), slightly modified. Briefly, $5 \mathrm{~mL}$ of blueberry extract were diluted with $10 \mathrm{~mL}$ of buffer solution $(0.025 \mathrm{M}$ potassium chloride $\mathrm{pH}=1.0$ or $0.4 \mathrm{M}$ sodium acetate $\mathrm{pH}=4.5)$.

The extracts were maintained in darkness during 30 minutes at room temperature. After that, the absorbance at 520 and $700 \mathrm{~nm}$ was measured (spectrophotometer Lambda 25, PerkinElmer). Total anthocyanin concentration was calculated in basis of the following equations:

$$
A=\left(A_{510 \mathrm{~mm}}-A_{700 \mathrm{~nm}}\right) \mathrm{pH} 1.0-\left(\mathrm{A}_{510 \mathrm{~nm}}-\mathrm{A}_{700 \mathrm{~nm}}\right) \mathrm{pH} 4.5
$$

TAC (mg cyaniding-3-glucoside $100 \mathrm{~g}^{-1}$ of fresh weight) $=(\mathrm{A} \times \mathrm{MW} \times \mathrm{DF} \times 1000 / \varepsilon \times \mathrm{L}) \times 21$

where $\mathrm{A}$ is the absorbance of extracts at different wavelength and $\mathrm{pH}, \mathrm{MW}$ corresponded to the molecular weight of cyanidin-3-glucoside $\left(449.2 \mathrm{~g} \mathrm{~mol}^{-1}\right)$, DF is the dilution factor, $\mathcal{E}$ is the molar absorptivity coefficient from cyanidin-3-glucoside $(26,900)$ y $\mathrm{L}$, is the cuvette optical pathlength $(1 \mathrm{~cm})$. Results were reported as $\mathrm{mg}$ of cyanidin3-glucoside $100 \mathrm{~g}^{-1}$ of fresh weight.
Totalphenols (TP)

Total phenols content was measured following the methodology of Rodriguez-Roque et al. (2013). Briefly, 0.2 $\mathrm{mL}$ of extract was mixed with $0.2 \mathrm{~mL}$ of Folin-Ciocalteu reagent and $2 \mathrm{~mL}$ of $20 \% \mathrm{Na}_{2} \mathrm{CO}_{3}$. The sample was made up at $10 \mathrm{~mL}$ with distilled water and maintained in darkness during an hour at room temperature. The absorbance at $725 \mathrm{~nm}$ was measured (spectrophotometer Lambda 25, PerkinElmer). Results were expressed as $\mathrm{mg}$ of gallic acid $100^{-1} \mathrm{mg}$ of fresh weight.

\section{Antioxidant capacity $(A C)$}

The antioxidant capacity was measured out according to the methodology indicated by Brand-Williams et al. (1995), with some modifications. A portion of $0.2 \mathrm{~mL}$ of extract was mixed with $3.8 \mathrm{~mL}$ of a methanolic DPPH (2,2diphenyl-1-picrylhydrazyl at $\left.0.025 \mathrm{~g} \mathrm{~L}^{-1}\right)$. Samples were maintained in darkness during $30 \mathrm{~min}$. The decrease in the DPPH radical absorbance at $515 \mathrm{~nm}$ was measured (spectrophotometer Lambda 25, PerkinElmer). Results were expressed as \% of DPPH inhibition as described in the following equation: \% DPPH inhibition $=\left(\frac{A_{0}-A_{1}}{A_{0}}\right) * 100$; where $\mathrm{A}_{0}$ is the initial absorbance (methanolic DPPH solution), $A_{1}$ is the absorbance of the sample.

\section{Statistical analysis}

The phenological event of flowering was modeled with Weibull (Pennypacker et al., 1980) through the 9.1.3 version of Statistical Analysis System (SAS) for Windows 2006. The Weibull model can be given in the following form of its integrated version (Ramírez-Legarreta et al., 2008):

$y=1-e^{\left[\left(\frac{t}{b}\right) c\right]}$, where: $y=$ flowering proportion per variety, $b=$ estimator of the flowering range in its inverse form $(1 / b), c=$ parameter of function of the curve form and lack of units, and $t=$ time measure in heat units with critical temperatures of 4 y $35^{\circ} \mathrm{C}$. The length and number of sprouts were tested by the non-parametric of Mann-Whitney $(\mathrm{p} \leq 0.05)$. The fruit quality data were subjected to an analysis of variance (ANOVA), when significant interaction or treatment effect was detected, the values were compared with Tukey's multiple means comparison procedure $(\mathrm{p} \leq 0.05)$, in which the statistical analysis program SAS 9.1.3 was used.

\section{Results and Discussion}

\section{Vegetative growth (length and number of sprouts)}

As it can be seen on Table 1, the sprouts length in the various varieties evaluated were statistically equal, yet it was observed that the treatment of gypsum, sulphur and compost showed the highest value $(26.3 \mathrm{~cm})$ in the 'Bluejay' ('Bj') and 'Duke' varieties. In that regard, it is well known that blueberry plants adapt easily to soils with high content of organic material $(>5 \%)$ and $\mathrm{pH}$ between 4.5 y 5.5 (Hummer et al., 2007), in this study, the application of compost favoured the availability of water, oxygen and nutrients, mainly nitrogen (Ochmian et al., 2013), however, 
it is probable that since it is the first cycle of evaluation the maximum availability of favorable facts has not been attained, since the quality (relation C-N) of the amendments can affect the processes of mineralization of nitrogen in the soil (Çelik et al., 2012), therefore it is expected that in the next growth cycle, the amendments will produce differences in the physicochemical soil conditions and consequently an emission of sprouts with more length, as it was reported by Haynes and Swift (1986) in evaluating the amendments with different types of organic residues and elemental sulphur for a period of two consecutive years.

The application of gypsum, sulphur and compost favored a significative increase in relation to the number of sprouts with an average value of 17.5 , being the 'Blueray' variety ('Br') which presented the best results, yet, it was statistically similar to what was observed in 'Duke' with 14 , which according to Giovanelli and Buratti (2009) can be associated with an increase of availability of interchangeable calcium, manganese, iron and aluminium, the product of gradual decrease in the values of acidity present in the rhizosphere. Additionally, Angeletti et al. (2010) indicate that blueberry due to its origin and native conditions in which it develops, a root system slight profuse and the number of sprouts that produces every growth cycle, is related to the variation in the accumulation of cold and nutrimental availability. Similar results were reported by Haynes and Swift (1986) in evaluating the effect of elemental sulphur (s), peat, (pine bark and the mixture of pine bark and elemental sulphur) on the growth and performance of blueberry 'Bluecrop' report that the best results were observed with the application of the mixture of pine bark and elemental sulphur.

\section{Blossom}

In figs. 1 and 2 it is shown the pattern of the stadium of flowering through two perspectives (Ramírez-Legarreta et al., 2008), the first one in function of the time scale in Gregorian calendar and the second by the accumulated thermal unit (TU) scale. In the first case it was observed a phase shift of dates in the beginning of flowering among varieties, since the flowering of 'Bj' and 'Br' started on April 21 and 26, respectively, but in 'Duke' it was detected May 14, a difference of 23 and 18 days, which could be an indicator for considering this last variety with potential avoidance of frost in the edaphoclimate conditions prevailing in the Cuauhtemoc region. In this regard Molina et al. (2008) point to 'Duke' as a variety with the characteristic of resistance to late frost and a need of 820 cold hours, conditions that according to Ramírez-Legarreta et al. (2008) and Ramírez et al. (2011) characterize it to a high degree in the present area of study; likewise, Çelik et al. (2012) indicate that this variety consolidate the fruit production in a brief period of time (early) and low sensitivity to mechanical damage, which makes this variety an excellent option for the consumption of fresh and processed fruit.

When analyzing the event through the TU approach accumulated based on the critical temperatures of 4.5 and $35^{\circ} \mathrm{C}$ and in function with the Weibull model (Table 2), the flowering curves show statistically different values among gradients, as well as their duration with regarding the need for accumulation of UT were also different, on the one hand, 'Bj' and 'Br' required 389 and 322 TU, respectively; due to this the flowering period was prolonged for 30 and 23 days, while in 'Duke' it was required 152 TU and in that way the process was more accelerated with only 12 duration days. On the other hand, 'Duke' with 95 and 152 TU were completed 5 and $95 \%$ flowering, which represents 40 and $53 \%$ of time in relation to ' $\mathrm{Bj}$ ' and ' $\mathrm{Br}$ ', and according to the frost probability curve (Fig. 2 ) shows $12.3 \%$ probability of suffering damage due to low temperatures, by comparison with the 52.39 and $42.07 \%$ of ' $\mathrm{Bj}$ ' and 'Br', this from an initial reference data of $5 \%$ flowering. On this regard 'Bj' and 'Br' as pointed by Ramírez-Legarreta et al. (2008) represent an increase of production costs related to the application of certain cultural management field practices to reduce the risk of damage by frost during flowering. Additionally, if it is taken into account that a descent of temperature of $-2{ }^{\circ} \mathrm{C}$ would damage the buds that are found in the most advanced stadiums and close to bud flowering, then for this reason the 'Duke' variety obtains the possibility of harvest at a lower production cost.

\section{Fruit quality}

It was not found significative interaction $(\mathrm{p} \leq 0.05)$ among varieties and amendments in any of the evaluated characteristics; therefore, the discussion of results was realized in function of individual factors.

Table 1. Length and number of shoots in cultivated blueberry varieties with different organic amendments applied to soil

\begin{tabular}{|c|c|c|c|}
\hline Varieties & Amendment & Length of shoots $(\mathrm{cm})$ & Number of shoots \\
\hline \multirow{3}{*}{ Bluejay } & $g+s$ & $18.2 \mathrm{a}^{*}$ & $9.0 \mathrm{bc}$ \\
\hline & $g+s+c$ & $26.3 a$ & $11.0 \mathrm{bc}$ \\
\hline & $g+s+c+p b$ & $14.7 \mathrm{a}$ & $8.0 \mathrm{c}$ \\
\hline \multirow{4}{*}{ Blueray } & $g+s$ & $19.6 \mathrm{a}$ & $13.5 \mathrm{bc}$ \\
\hline & $g+s+c$ & $17.2 \mathrm{a}$ & $17.5 \mathrm{a}$ \\
\hline & $g+s+c+p b$ & $14.3 \mathrm{a}$ & $9.0 \mathrm{c}$ \\
\hline & $g+s$ & $19.4 \mathrm{a}$ & $15.0 \mathrm{ab}$ \\
\hline \multirow{2}{*}{ Duke } & $g+s+c$ & $24.3 a$ & $14.0 \mathrm{abc}$ \\
\hline & $g+s+c+p b$ & $17.5 \mathrm{a}$ & $5.0 \mathrm{~d}$ \\
\hline
\end{tabular}


454

Table 2. Indicators from the Weibull model modified to the stadium of flowering in varieties of blueberry cultivated with amendments applied to soil

\begin{tabular}{|c|c|c|c|c|c|}
\hline \multirow{2}{*}{ Varieties } & Weibull model & \multicolumn{3}{|c|}{ Indicators of model adjustment } & \multirow{2}{*}{$\begin{array}{c}\text { TU between } 5 \text { and } 95 \% \\
\text { flowering }\end{array}$} \\
\hline & $\mathrm{Y}=1-\mathrm{e}^{[-(\mathrm{t} / \mathrm{b}) \mathrm{c}]}$ & Value grade $(1 / \mathrm{b})$ & $\mathrm{R}^{2}(\%)$ & $\mathrm{CV}(\%)$ & \\
\hline Bluejay & $\mathrm{Y}=1-\mathrm{e}^{[-(t / 417.8) 1.6869]}$ & 23.91E-04 a* & 99.7 & 3.3 & 389 \\
\hline Blueray & $\mathrm{Y}=1-\mathrm{e}^{[-(\mathrm{t} / / 10.4) 2.3827]}$ & $24.38 \mathrm{E}-04 \mathrm{a}$ & 99.1 & 5.3 & 322 \\
\hline Duke & $\mathrm{Y}=1-\mathrm{e}^{[-(t / 50.1 .1) \cdot 9.9419]}$ & $19.95 \mathrm{E}-04 \mathrm{~b}$ & 96.7 & 12.6 & 152 \\
\hline
\end{tabular}

Note: Flowering according to variety in percentage is obtained by substituting in the equation the value of $\mathrm{t}$ (which represents accumulated heat units between 72 and 462 for Bluejay, 118 and 440 for Blueray and between 360 and 512 for Duke variety, the result or value of Y is multiplied by 100 . CV: Coefficient of variation. Means with the same letter in the grade column $(1 / \mathrm{b})$ signify statistical equality between them with $95 \%$ certainty.

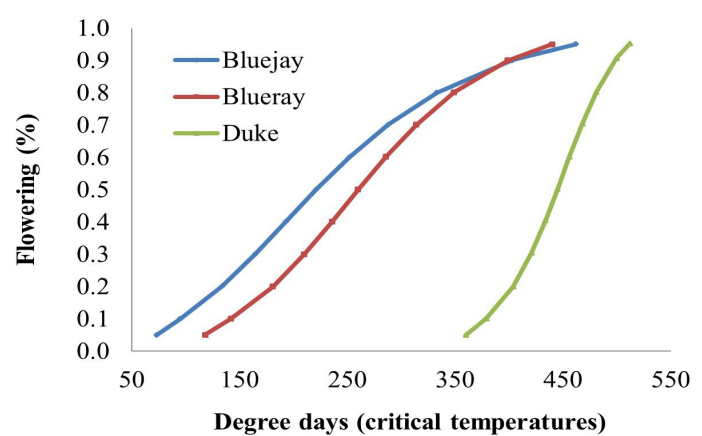

Fig. 1. Accumulation of needed heat units for the beginning of flowering stadium per blueberry varieties

\section{Varieties}

The content of total soluble solids is closely correlated to the presence of sugars (glucose and fructose) and in a lesser degree to organic acids and pectic substances (Mditshwa et al., 2017). In this investigation, by comparing varieties, it was found that the concentration of TSS was not significant $(\mathrm{p} \leq 0.05)$ and its values fluctuated between 9.4 and $10^{\circ} \mathrm{Brix}$, with a difference from 4 and 6\% between 'Duke' and ' $\mathrm{Bj}$ ' in relation to 'Br' (Table 3). Values between 12.2 and 12.8 ${ }^{\circ}$ Brix were detected by Lobos et al. (2011) in highbush blueberry ( $V$. corymbosum L.) 'Elliot' subject to foliar applications of calcium. Likewise, Hummer et al. (2007) reported for blueberry 'Biloxi', 'Misty', 'Sharpblue', 'Sapphire', 'Jewel' and 'Emerald' ( $V$. corymbosum L) values of $12.3,13.3,13.2,12.1,12.2$ and $12.3^{\circ}$ Brix, respectively. By comparison, fruit acidity was statistically different with values that fluctuated between 4.1 and 4.3 among which stand out ' $\mathrm{Bj}$ ' and 'Br', these results exceed what is indicated by Molina et al. (2008) and Angeletti et al. (2010) for blueberry 'O'Neal', 'Sharpblue' and 'Misty' (3.2 y 2.8, in both cases) and 'O'Neal' and 'Bluecrop' (3.75 and 3.31), respectively; it is important, if it is considered as a parameter in the determination of flavour and as consequence to acceptance level by the end consumer. Likewise, fruit color in its diverse components (brightness (L), purity (chromaticity) colour tone (hue angle) showed statistical equality among varieties; which according to Mditshwa et al. (2017) could be associated with the homogeneity in regard to ripeness level of the fruits analyzed.

The principal component responsible for the characteristic blue coloration in the fruit of blueberry are the anthocyanins (Michalska and Łysiak, 2015), which values fluctuate between 105 and $250 \mathrm{mg}$ cyanidina-3glucosid $100 \mathrm{~g}^{-1}$ and were statistically equal among themselves (Table 3), yet, what was found in 'Bj' exceeds the

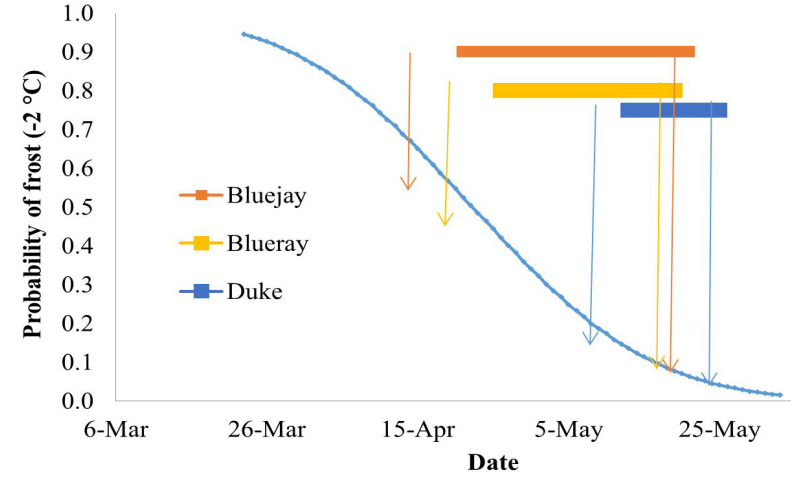

Fig. 2. Flowering period of blueberry varieties and probability of occurrence of frost $\left(-2{ }^{\circ} \mathrm{C}\right)$ in the region of Cuauhtémoc, Chihuahua, Mexico

concentration of total anthocyanins reported by Çelik et al. (2012) in this same variety with $120.875 \mu \mathrm{g}$ cyanidina-3glucosid $\mathrm{g}^{-1}$, on their part 'Br' and 'Duke' present similar values to 'Brigitta' and 'Patriot' (105.857 and $180.288 \mu \mathrm{g}$ cyanidina-3-glucosid $\mathrm{g}^{-1}$, respectively) pointed by the same authors. The presence of TP was statistically different among varieties where stands out ' $\mathrm{Bj}$ ' with $701.6 \mathrm{mg}$ gallic acid $100 \mathrm{~g}^{-1}$ which is higher than what is shown by 'Duke' (381.4 gallic acid $100 \mathrm{~g}^{-1}$ ). The results obtained by this work contrast with those obtained by Giovanelli and Buratti (2009) who in evaluating polyphenolic composition and antioxidant activity in cultivated and wild blueberry present in Italy, report values between 251 and $298 \mathrm{mg}$ gallic acid $100 \mathrm{~g}^{-1}$ (commercial varieties) ( $V$. corymbosum $\mathrm{L}$ ) and in the wild (577 and $614 \mathrm{mg}$ gallic acid $100 \mathrm{~g}^{-1}$ ) ( $V$. myrtillus). Additionally all the analyzed varieties with regard to TP are higher than what is reported by Ochmian (2013) in 'Emil' and 'Putte' ( $V$. angustifolium) with 212 and $271 \mathrm{mg}$ gallic acid $100 \mathrm{~g}^{-1}$, respectively; the variation among results can be due to labor effect in agronomical management (pruning and fertilization sources) as suggested by Çelik et al. (2012) and Mditshwa et al. (2017), fruit intrinsic characteristics (ripeness level) (Crecente-Campo et al., 2012; Michalska and Łysiak, 2015), prevalent environmental conditions during growth and development (temperature and photoperiod) (Muñoz-Vega et al., 2016) and the extraction and evaluation method (Ochmian, 2013).

Furthermore, one of the attributes for which the blueberry fruit stands out and is an incentive for the increase in its production and demand level, is its high concentration of anthocyanins (conjugate of 3-O-glucosid and its derivatives) (Brito et al., 2014), vitamin C and total phenolic compounds (Correa et al., 2017), compounds that can delay or inhibit lipids oxidation and of other molecules through the inhibition of reactive oxygen species (radical 
anion superoxide $\left(\mathrm{O}_{2}^{-}\right)$, hydrogen peroxide and hydroxide ion $\left(\mathrm{OH}^{-}\right)$, among others) (Rodríguez-Roque et al., 2013). In this work, the fruits were characterized by presenting high levels of antioxidant capacity, mainly 'Bj' and 'Br' (91.5 and $89.1 \% \mathrm{DPPH}$ inhibition), this in agreement with the described performance for the TP, although 'Br' showed a different value and TA which was similar among these.

\section{Amendments}

Among the fruits destined for fresh produce market, acceptance level by the consumer is defined in a subjective manner by the grade of sweetness (sugar and other compounds' concentration) and the conjugation of other characteristics of organoleptic quality (color, smell, firmness and shape) (Correa et al., 2017). In this project, the combined application of gypsum and sulphur, and when compost is added, showed better results in regard to TSS concentration $\left(9.8^{\circ} \mathrm{Brix}\right.$, in both cases) in comparison with fruits originating from plants where pine bark was included (Table 4). In this regard, Paal et al. (2011) indicate that the effectiveness of the application of organic amendments greatly affects the process of mineralization of $\mathrm{N}$ in the soil, by producing competition with this element, among the microorganisms involved in its transformation and in the root system, which absorption level tends to be high, especially in the growth stages where predominate the formation of branches and leaves (Muñoz-Vega et al., 2016), a situation that is aggravated by the presence of soils with high levels of $\mathrm{pH}$ (Correa et al., 2017), a condition similar to the presented one with a $\mathrm{pH}$ value (6.6) of reference in the study site. In some varieties such as 'Brigitta', 'Patriot', 'Bluecrop', 'Darrow' and 'Bluejay' cultivated in conventional and organic systems, Çelik et al. (2012) report values that fluctuate between 9.817 and 10.273 , and 10.333 and $11.267^{\circ}$ Brix, respectively, where in the particular case of ' $\mathrm{Bj}$ ' the authors observed an increase from 9.900 to $10.817{ }^{\circ} \mathrm{Brix}$, that is, $8.47 \%$ in its concentration. On their part, Molina et al. (2008) in the varieties 'O'Neal', 'Sharpblue' and 'Misty' ( $V$. corymbosum) cultivated in Spain in open field and conditions of protected agriculture (macro tunnel), report values of $9.8,12.4$ and $12.7^{\circ}$ Brix

The acidity in fruits fluctuated between 4.1 and 4.2, without finding significant variation among the amendments, however, these exceed what is reported by Paal et al. (2011) but were inferior to what is indicated for blueberry 'O'Neal' and 'Bluecrop' (4.41 and 7.1, respectively) by Angeletti et al. (2010). Among the amendments applied no variation was found concerning purity (chromaticity) and color tone ('hue), however, a color component as brightness showed different statistics when this was evaluated in fruits originating from plants that developed in the presence of gypsum, sulphur and compost. In this sense, all the berries harvested for this investigation presented intense blue color hue, and in accord to what is pointed out by Brito et al. (2014), this pattern can be associated with the content of anthocyanins, which, in our case, even when such pigment showed high levels, it was not significant among the amendments. Nonsignificant values among the components of color, were reported in strawberry (Fragaria $\times$ ananassa Duch) 'Selva' by Crecente-Campo et al. (2012) when comparing a conventional and an organic system.

In the basis of the present conditions in the soil for this research (texture, percentage organic material, $\mathrm{pH}$ etc.), the application of amendments did not produce significant changes $(\mathrm{p} \leq 0.05)$ on TA $(107.2,169.3$ and $169.3 \mathrm{mg}$ cyanid-3-glucosid $100 \mathrm{~g}^{-1}$ ) and $387.9,454.1$ and $461.2 \mathrm{mg}$ gallic acid $100 \mathrm{~g}^{-1}$ for TP, even when showing the same performance among these. It was observed that the application of gypsum and sulphur, as well as the addition of compost corresponded to the higher levels (Table 4); which

Table 3. Parameters of fruit quality in varieties of blueberry grown with amendments applied to the soil

\begin{tabular}{|c|c|c|c|c|c|}
\hline \multirow{2}{*}{ Varieties } & \multirow{2}{*}{ TSS $\left({ }^{\circ}\right.$ Brix $)$} & \multirow{2}{*}{$\mathrm{pH}$} & \multicolumn{3}{|c|}{ Color } \\
\hline & & & $\mathrm{B}$ & $\mathrm{C}$ & Hue $\left(^{\circ}\right)$ \\
\hline Bluejay & $9.7 a^{*}$ & $4.3 \mathrm{a}$ & $95.4 \mathrm{a}$ & $19.2 \mathrm{a}$ & $233.6 \mathrm{a}$ \\
\hline Blueray & $10.0 \mathrm{a}$ & $4.2 \mathrm{ab}$ & $93.2 \mathrm{a}$ & $14.9 \mathrm{a}$ & $195.7 \mathrm{a}$ \\
\hline \multirow[t]{2}{*}{ Duke } & $9.4 \mathrm{a}$ & $4.1 \mathrm{~b}$ & $90.1 \mathrm{a}$ & $16.2 \mathrm{a}$ & $228.3 \mathrm{a}$ \\
\hline & \multicolumn{2}{|c|}{ TA (mg cyanid-3-glucosid $100 \mathrm{~g}^{-1}$ ) } & TP $\left(\mathrm{mg}\right.$ gallic acid $\left.100 \mathrm{~g}^{-1}\right)$ & \multicolumn{2}{|c|}{$\mathrm{AC}(\% \mathrm{DPPH}$ inhibition $)$} \\
\hline Bluejay & \multicolumn{2}{|c|}{$250.4 \mathrm{a}$} & $701.6 \mathrm{a}$ & \multicolumn{2}{|c|}{$91.5 \mathrm{a}$} \\
\hline Blueray & \multicolumn{2}{|c|}{$170.3 \mathrm{a}$} & $456.8 \mathrm{~b}$ & \multicolumn{2}{|c|}{$89.1 \mathrm{ab}$} \\
\hline Duke & \multicolumn{2}{|c|}{$105.0 \mathrm{a}$} & $381.4 \mathrm{c}$ & \multicolumn{2}{|c|}{$79.5 \mathrm{~b}$} \\
\hline
\end{tabular}

Table 4. Amendments applied to the soil and its effect on quality parameters in blueberry fruit

\begin{tabular}{|c|c|c|c|c|c|}
\hline \multirow{2}{*}{ Amendments } & \multirow{2}{*}{ TSS $\left({ }^{\circ}\right.$ Brix $)$} & \multirow{2}{*}{$\mathrm{pH}$} & \multicolumn{3}{|c|}{ Color } \\
\hline & & & B & $\mathrm{C}$ & Hue $\left(^{\circ}\right)$ \\
\hline$g+s$ & $9.8 a^{*}$ & $4.1 \mathrm{a}$ & $79.60 \mathrm{~b}$ & $20.6 a$ & $216.6 a$ \\
\hline$g+s+c$ & $9.8 \mathrm{a}$ & $4.2 \mathrm{a}$ & $94.36 \mathrm{a}$ & $16.2 \mathrm{a}$ & $235.1 \mathrm{a}$ \\
\hline \multirow[t]{2}{*}{$g+s+c+p b$} & $8.5 \mathrm{~b}$ & $4.1 \mathrm{a}$ & $71.26 \mathrm{~b}$ & $18.8 \mathrm{a}$ & $213.2 \mathrm{a}$ \\
\hline & \multicolumn{2}{|c|}{ TA (mg cyanid-3-glucosid $100 \mathrm{~g}^{-1}$ ) } & TP $\left(\right.$ mg gallic acid $\left.100 \mathrm{~g}^{-1}\right)$ & \multicolumn{2}{|c|}{ AC (\% DPPH inhibition) } \\
\hline$g+s$ & \multicolumn{2}{|c|}{$107.2 \mathrm{a}$} & $461.2 \mathrm{a}$ & \multicolumn{2}{|c|}{$82.5 \mathrm{~b}$} \\
\hline$g+s+c$ & \multicolumn{2}{|c|}{$183.4 \mathrm{a}$} & $454.1 \mathrm{a}$ & \multicolumn{2}{|c|}{$91.4 \mathrm{a}$} \\
\hline$g+s+c+p b$ & \multicolumn{2}{|c|}{$169.3 \mathrm{a}$} & $387.9 \mathrm{a}$ & \multicolumn{2}{|c|}{$88.8 \mathrm{ab}$} \\
\hline
\end{tabular}


456

according to Crecente-Campo et al. (2012) can be explained by the role played by TA and TP in the prevention of plant sickness and phytosanitary protection, whereby they are synthetized and accumulated for their own defense (Brito et al., 2014). The fruits harvested from cultivated plants with gypsum, sulphur and compost presented a value of antioxidant capacity of $91.4 \% \mathrm{DPPH}$ inhibition, however, statistically it was similar to what was found among those to which it was added pine bark $(88.8 \%$ DPPH inhibition). Recent research show that the application of materials which management considered organic (compost, vermi-compost, organic residues, etc.) increase the content of diverse bio-actives, among them vitamin $\mathrm{C}$ and phenolic compounds (Mditshwa et al., 2017), highly correlated with the performance of antioxidant capacity. Which according to Hummer et al. (2007) agree with the creation and predominance of favourable characteristics for the development of microbic fauna such as the presence of mineralizable carbon and enzymatic elements (phosphatase and dehydrogenase) which help with the liberation of nutrimental elements which affect directly the growth and development of roots (Michalska and Łysiak, 2015).

\section{Conclusions}

Blueberry farming in the Cuauhtemoc Chihuahua region can be a viable alternative for apple producers, if one considers the 'Duke' variety, which characteristics of vegetative growth and delayed flower development, permit a greater probability of frost avoidance, where the application of gypsum, sulphur and compost favour its adaptation. On the other hand, fruit quality, specifically the content of TSS and colour brightness are slightly affected by the application of amendments, and with the exception of $\mathrm{AC}$, the content of bio-active compounds (TA and TP) show no variation, where the application of gypsum, sulphur and compost is an important option for management if only this characteristic is taken into consideration.

\section{Acknowledgements}

The authors express their gratitude to the company La norteñita S.A. de C.V. and to PRODEP-UACH-PTC-330, for the technical and financial support granted for the completion of the present research.

\section{References}

Angeletti B, Castagnasso H, Miceli E, Terminiello L, Concellón A, Chaves A, Vicentea AR (2010). Effect of preharvest calcium applications on postharvest quality, softening and cell wall degradation of two blueberry (Vacinium corymbosum) varieties. Postharvest Biology and Technology 58:98-103.

Brand-Williams W, Cuvelier ME, Berset C (1995). Use of a free radical method to evaluate antioxidant activity. Lebensmittel-Wissenschaft \& Technologie 22:25-30.

Brito A, Areche C, Sepúlveda B, Kennelly EJ, Simirgiotis MJ (2014). Anthocyanin characterization, total phenolic quantification and antioxidant features of some Chilean edible berry extracts. Molecules 19(8):10936-10955.

Çelik H, Özgen M, Saraçoğlu O (2012). Organik ve standart olarak yetiştirilen bazı yüksek moylu maviyemiş (Vaccinium corymbosum $\mathrm{L}$.) çeşitlerinin fitokimyasal içerikleri ile antioksidan kapasitelerinin karşlaşturlması [Comparison of phytochemicals and antioxidant capacities of some standard and organically grown highbush blueberries (Vaccinium corymbosum L.).]. Journal of Agricultural Sciences 18:167176.

Correa DMG, Vizzotto M, Picolotto L, Correa ALE (2017). Production, physical-chemical quality and bioactive compounds of misty blueberry fruit under different pruning intensities. Revista Brasileira de Fruticultura39(e-158):1-6.

Crecente-Campo J, Nunes-Damaceno M, Romero-Rodríguez MA, Vazquez-Odériz ML (2012). Color, anthocyanin pigment, ascorbic acid and total phenolic compound determination in organic versus conventional strawberries (Fragaria $\times$ ananass $a$ Duch, cv Selva). Journal of Food Composition and Analysis 28(1):23-30.

Giovanelli G, Buratti S (2009). Comparison of polyphenolic composition and antioxidant activity of wild Italian blueberries and some cultivated varieties. Food Chemistry 112:903-908.

Haynes RJ, Swift RS (1986). Effect of soil amendments and sawdust mulching on growth, yield and leaf nutrient content of highbush blueberry plants. Scientia Horticulturae 29:229-238.

Hummer K, Zee F, Straus A, Kejth L, Nishijima W (2007). Evergreen production of southern highbush blueberries in Hawaili. Journal of the American Pomological Society 1:188-195.

Lobos MT, Pinilla QH, Lobos AW (2011). Efecto de aplicaciones de calcio en la calidad de la fruta de arándano alto (Vaccinium corymbosum $\mathrm{L}$.) cv. Elliot [Effect of calcium applications on the quality of highbush blueberry fruitcv. Elliott].IDESIA 29: 59-64.

Mditshwa M, Samukelo ML, Zeray TS, Mbili N (2017). Postharvest quality and composition of organically and conventionally produced fruits: A review. Scientia Horticulturae 216:148-159.

Michalska A, Łysiak G (2015). Bioactive compounds of blueberries: postharvest factors influencing the nutritional value of products. International Journal of Molecular Sciences 16(8):18642-18663.

Molina JM, Calvo D, Medina JJ, Barrau C, Romero F (2008). Fruit quality parameters of some southern highbush blueberries (Vaccinium $\times$ corymbosum L.) grown in Andalusia (Spain). Spanish Journal of Agricultural Research 6(4):671-676.

Muñoz-Vega P, Paillán H, Serri H, Donnay D, Sanhueza C, Merino E, HirzelJ (2016).Effects of organic fertilizers on the vegetative, nutritional, and productive parameters of blueberries 'Corona', 'Legacy', and 'Liberty'. Chilean Journal of Agricultural Research 76(2):201-212.

Ochmian I (2013). Growth, yield and fruit quality two cultivars lowbusch blueberry. Acta Scientiarum Polonorum Hortorum Cultus 12(2):8796.

Ordoñez BMF, Jacobo CJL, Quintana LE, Parra QRA, Guerrero PVM, Ríos VC (2016). Pulgón lanígero e impacto ambiental por el uso de pesticidas en manzano en Chihuahua, México [Woolly aphid and environmental impact of pesticide use in apple tree in Chihuahua, Mexico]. Revista Mexicana de Ciencias Agrícolas 7(3):573-583. 
Ortiz SCA (1987). Elementos de agrometeorología cuantitativa: con aplicaciones en la República Mexicana [Elements of quantitative agrometeorology: with applications in the Mexican Republic]. Universidad Autónoma Chapingo: Departamento de Suelos. Texcoco, Mexico.

Paal T, Starast M, Noormets-Sanski M, Vool E, Tasa T, Karp K (2011). Influence of liming and fertilization on lowbush blueberry in harvested peat field condition. Scientia Horticulturae 130:157-163.

Pennypacker SP, Knoble HD, Antle CE, Madden LV (1980). A flexible model for studying plant disease progression. Phytopathology 70(3):232-235.

Ramírez LMR, Ruiz CJA, Medina GG, Jacobo CJL, Parra QRA, Ávila MMR, Amado AJP (2011). Perspectivas del sistema de producción de manzano en Chihuahua, ante el cambio climático [Perspectives on the apple production system in Chihuahua facing climate change]. Revista Mexicana de Ciencias Agrícolas 2:265-279.

Ramírez-Legarreta MR, Jacobo-Cuéllar JL, Gardea-Béjar AA, ParraQuezada RA (2008). Modelo de desarrollo floral en manzanos [Malus sylvestris (L.) Mill. var. domestica (Borkh) Mansf.] Red Delicious y Golden Delicious como herramienta de toma de decisiones en el manejo integrado de enfermedades [Model on floral development of apple [Malus sylvestris(L.) Mill. var.domestica (Borkh) Mansf.] Red and Golden Delicious as a decision-making tool for integrated disease management]. Revista Mexicana de Fitopatología 26(2):153-163.
Ríos FJL, Torres MM, Ruíz EMJA (2017). Productividad del agua en manzano producido bajo diferentes niveles de tecnificación en Cuauhtémoc, Chihuahua, México [Water productivity in apple tree produced under different levels of tecnification in Cuauhtemoc, Chihuahua, Mexico]. Asuntos Económicos y Administrativos 32:135146.

Rodríguez-Roque MJ, Rojas-GraüMA, Elez-Martínez P, Martín-Belloso O (2013). Changes in vitamin C, phenolic, and carotenoid profiles throughout in vitro gastrointestinal digestion of a blended fruit juice. Journal of Agricultural andFood Chemistry 61:1859-1867.

ALIS (2017). Agricultural and Livestock Information System. Agroalimentary Atlas 2017. Secretary of Agriculture, Livestock, Rural Development, Fisheries and Food (in Spanish). Retrieved 2018 March 12 from http://online.pubhtml5.com/clsi/ibhs/.

Wrolstad RE (1976). Color and pigment analyses in fruit products. Corvallis, OR: Oregon State University. Oregon, USA. 